American University Washington College of Law

Digital Commons @ American University Washington College of

Law

Articles in Law Reviews \& Other Academic Journals

Scholarship \& Research

2010

A Survey of Federal Agency Rulemakers' Attitudes About ERulemaking

Jeffrey Lubbers

Follow this and additional works at: https://digitalcommons.wcl.american.edu/facsch_lawrev

Part of the Administrative Law Commons, and the Legislation Commons 


\title{
A SURVEY OF FEDERAL AGENCY RULEMAKERS' ATTITUDES ABOUT E-RULEMAKING
}

\author{
JEFFREY S. LUBBERS*
}

\section{TABLE OF CONTENTS}

I. Background on Rulemaking in the United States

A. Electronic Rulemaking (e-Rulemaking)

B. Impact of e-Rulemaking on the Agencies

II. The Survey.

A. Positive Effects of e-Rulemaking (from the Rulemakers'

Perspective)

B. Worrisome Effects of e-Rulemaking (from the Rulemakers'

Perspective)

C. Other Effects of e-Rulemaking (from the Rulemakers'

Perspective)

D. Rulemakers' General Comments on e-Rulemaking

1. Generally Positive Comments.

2. Generally Negative Comments

Conclusion

Appendix

\section{BACKGROUND ON RULEMAKING IN THE UNTED STATES}

In the United States, the 1946 Administrative Procedure Act (APA) contains the general requirements for federal agency promulgation of regulations. This procedure is often called notice-and-comment rulemaking, deriving from the fact that the operative APA section requires

* Professor of Practice in Administrative Law, American University Washington College of Law. This Article was prepared originally to appear as a chapter in the forthcoming book CONNECTING Democracy: ONLINE CONSLlTation aNd THE FUTURE of Democratic Discourse (Stephen Coleman \& Peter M. Shane eds., anticipated 2010). 
(1) publication of a notice of proposed rulemaking, (2) opportunity for public participation in the rulemaking by submission of written comments, and (3) publication of a final rule and accompanying statement of basis and purpose not less than thirty days before the rule's effective date.

These requirements may be exceeded by agencies voluntarily or pursuant to other programmatic statutes that provide more elaborate public procedures. However, even this procedural floor does not apply to all rulemaking. Certain types of rules are exempted from some of these requirements, and entire classes of rules are totally exempted from APA notice-and-comment requirements. These exemptions reflect the APA drafters' cautious approach to imposing procedural requirements on a myriad of agency functions, as well as their willingness, in some situations, to permit agencies a measure of discretion in fashioning procedures appropriate to the particular rulemaking involved. This basic APA model has proved successful and is being emulated around the world.'

\section{A. Electronic Rulemaking (e-Rulemaking)}

With the technological revolution wrought by the Internet, the character of rulemaking is changing. What once was an all-paper process-with paper notices published in a paper Federal Register, paper comments submitted by hand or by post to the agency and filed in a filing cabinet in a room in the bowels of an agency-has been largely replaced by an electronic process with electronic notices, comments, and dockets available for anyone around the world to access with a click of a computer mouse. The U.S. Government has established a government-wide web portal that allows the public to file comments on any pending rule. ${ }^{2}$

Much has been written about this "rulemaking revolution," even though it is clearly in its early stages. ${ }^{3}$ The main touted benefits from e-

1. See, e.g., Jeffrey S. Lubbers, Notice-and-Comment Rulemaking Comes to China, ADMIN. \& REg. L. NEwS, Fall 2006, at 5, 5-6 (describing recent experiments by large Chinese municipalities with public comment procedures); Katsuya Uga, Development of the Concepts of "Transparency" and "Accountability" in Fapanese Administrative Law, I U. TOKYO J.L. \& POL. 25, 36-38 (2004) (describing the public comment procedures in Japan). However, for a lamentation about how the "basic model" has become overly laden with other review and analysis requirements in the United States, see Jeffrey S. Lubbers, The Transformation of the U.S. Rulemaking Process - For Better or Worse, 34 OHIO N.U. L. REv. 469, 473-78 (2008).

2. The website address is http://www.regulations.gov (last visited Mar. 22, 2010). For a comprehensive discussion of the history, goals, and remaining challenges of this effort, see Committee on the Status and Future of Federal E-Rulemaking, Achieving the Potential: The Future of Federal E-Rulemaking (2008), http://resource.org/change.gov/ceri-report-web-version.fixed.pdf.

3. Much of the following discussion is derived from JeFrREY S. LLBBERS, A Guide to Federal AGENCY Rulemaking 217-39 (4th ed. 2006). For a succinct history of the "rise of 
rulemaking, of course, are increased opportunities for information dissemination, public participation, and governmental transparency, along with better outcomes and greater trust in government. Commenters can now e-mail their comments to the agency with just a keystroke and agencies can post all comments on their websites for everyone in cyberspace to read and react to. The days of having to travel to Washington to physically visit a dusty records repository are over. Possibilities abound for enhancing the entire notice-and-comment process. ${ }^{4}$

In e-rulemaking, notices can be improved and more widely disseminated. ${ }^{5}$ Automatic notices can be generated by request to individuals who have requested them. Notices can be made wordsearchable, and alternative or revised drafts can be posted with the changes clearly designated. Moreover, related studies, required draft regulatory analyses, and other information can be linked to the notices to provide easier public access. The comment process can also be made much more "user-friendly" and responsive to agency needs through the use of requestfor-comments forms, the segmentation of proposed rules for comments, and opportunities to file reply comments ${ }^{6-}$ even producing "threads" of

e-rulemaking," see Cary Coglianese, E-Rulemaking: Information Technology and the Regulatory Process, 56 ADmIN. L. REv. 353, 363-66 (2004). See also Stuart W. Shulman, E-Rulemaking: Issues in Current Research and Practice, 28 INT'L J. PUB. ADMIN. 621 (2005); Beth Simone Noveck, The Electronic Revolution in Rulemaking, 53 EMORY L.J. 433 (2004); Barbara H. Brandon \& Robert D. Carlitz, Online Rulemaking and Other Tools for Strengthening Our Civil Infrastructure, 54 ADMIN. L. REV. 1421 (2002); Stephen Zavestoski \& Stuart W. Shulman, The Internet and Environmental Decision Making: An Introduction, 15 ORG. \& ENV'T 323, 326 (2002). Links to some of these and many other related papers and studies are available on the website of the Harvard University's John F. Kennedy School of Government's Regulatory Policy Program. John F. Kennedy School of Government, E-Rulemaking Papers \& Reports, http://www.hks.harvard.edu/m-rcbg/rpp/erulemaking/papers\&reports.htm (last visited Mar. 22, 2010).

4. Note, however, that the Administrative Procedure Act's (APA's) notice requirement is not met when an agency gives notice of a proposed rule only on the Internet instead of in the Federal Register. Util. Solid Waste Activities Group v. EPA, 236 F.3d 749, 754 (D.C. Cir. 2001).

5. Many of the ideas in this paragraph for enhanced citizen participation through erulemaking are discussed more fully in Noveck, supra note 3, at 471-94.

6. As one agency expert described it,

[W] can say the comment period ends on November lst. From November Ist, for example, to December 1st, we're going to allow anybody to come back and reply to what someone else has said. Not say something new, but reply to what others said. It will help the agency, at least theoretically, [to] more efficiendly address the comments that they've received.

Neil Eisner, Dep't of Transp., Comments at American University's Center for Rulemaking's $\begin{array}{lllll}\text { E-Rulemaking } & \text { Conference } & 77 & \text { Jan. } & 8,\end{array}$ http://www.american.edu/academic.depts/provost/rulemaking/transcripts.pdf. 
comments on particular issues. And the final stage of rulemaking can be enhanced through new publication techniques, such as linking all other related regulatory documents and final regulatory analyses, and grouping comments and the agency's response.

Others have focused on the possibilities of using these electronic tools for more interactive rulemaking. ${ }^{7}$ Suggestions for "deliberative dialogue[s]," online chat rooms, ${ }^{9}$ or electronic negotiated rulemaking concerning proposed regulations have proliferated, but so far their potential is untapped. ${ }^{10}$

It remains to be seen whether e-rulemaking will revolutionize public participation. As one leading commentator has concluded, "Electronic rulemaking may transform the process fundamentally or it may simply digitize established paper-based processes." 11 The route that e-rulemaking takes in the future may depend on how well a series of legal and technical questions can be answered. ${ }^{12}$

But if the process is to be transformative, this transformation of the rulemaking (and docketing) process should be viewed as having two main purposes. The first is an informational one of providing a global, seamless view of each rulemaking, and the second is a participatory one.

Achieving the informational goal means providing access to every meaningful step in the generation of a rule, from the statute enacted by Congress that authorizes the rule to the earliest agency action (perhaps an "advance notice of proposed rulemaking") to the last step in the process whether it be the final rule, a decision in a court challenge, or later agency amendments, interpretations, guidelines, or enforcement actions. ${ }^{13}$ It also

7. See, e.g., Thomas C. Beierle, Discussing the Rules: Electronic Rulemaking and Democratic Deliberation 8-13 (2003) (Res. for the Future, Discussion Paper No. 03-22, 2003), http://www.rff.org/rff/Documents/RFF-DP-03-2.pdf.

8. Noveck, supra note 3 , at 499.

9. Stephen M. Johnson, The Internet Changes Everything: Revolutionizing Public Participation and Access to Government Information Through the Internet, 50 ADMIN. L. REV. 277, 321-24 (1998) (discussing early experiments by the Nuclear Regulatory Commission).

10. See, e.g., Beierle, supra note 7 , at 8 (discussing some agency attempts to use dialogues in rulemaking).

11. Stuart W. Shllman, The Internet Still Might (but Probably Won't) Change Everything: Stakeholder Views ON THE Future OF Electronic RULEMAKING 35 (2004), http://erulemaking.ucsur.pitt.edu/doc/reports/erulemaking_final.pdf.

12. The following discussion is adapted from Jeffrey S. Lubbers, The Future of Electronic Rulemaking: A Research Agenda John F. Kennedy Sch. of Gov't, Harvard Univ., Regulatory Policy Program, Working Paper No. RPP-2002-04, 2002), http://www.hks.harvard.edu/mrcbg/research/rpp/RPP-2002-04.pdf, reprinted in ADMIN. \& REG. L. NEws, Summer 2002, at 6 .

13. I am indebted to Professor Cary Coglianese for this insight. 
means that the public should be provided a "vertical" view of pending or final rules-what might be called "drilling down" into the meaningful agency and outside studies and analyses that are now found in the docket, along with the public comments, for any significant proposed and final rule-and, where possible, through links into those secondary studies and analyses referenced in the primary studies.

The participatory goal of the transformation of rulemaking is ultimately to make it possible for participants to participate in real time with other stakeholders in a rulemaking process (an idealized "chat room") that will allow a more rational, interactive, and less adversarial path to an optimum final rule. And as information-filtering technologies (à la Google) become more sophisticated and allow more tailoring for individualized needs, commenters will also be able to zero in on their particular interests and contribute more targeted comments. ${ }^{14}$

Both the informational and participatory goals raise issues which require further research and experimentation. Informational issues include: the ways to best integrate existing sources of information and docketing concerns, such as those related to scanning, archiving, handling of attachments, copyright, authentication, security, and privacy. Participatory issues include: how to best reach the goal of better, more targeted notices; the possibility of providing easier, more convenient comment opportunities; what rules should govern rulemaking "chatrooms"; and the broad question of electronic "negotiated rulemaking." 15

\section{B. Impact of $e^{-R u l e m a k i n g ~ o n ~ t h e ~ A g e n c i e s ~}$}

The flip side of increased public participation, of course, is increased responsibilities on agencies to digest and react to a higher volume of comments. Blizzards of comments have become increasingly common in controversial rulemakings, and e-rulemaking can only further this trend. Professor Strauss has warned of some of the problems this might cause:

I think we're going to see an enormous explosion in the volume of rulemaking comments, and some of them will be quite manipulative. And it will be a challenge for the agencies receiving these comments to tell the one from the other, the valid from the invalid. And then, once they have received hundreds of thousands, tens of thousands of comments, the impulse to treat them as a reflection of e-democracy-we're hearing from the people, and what we do ought to reflect the people, rather than we are collecting

14. Professor Stuart Shulman persuasively illustrated this last point in a presentation at the Fall 2005 meeting of the American Bar Association Section of Administrative Law and Regulatory Practice.

15. For more on these issues, see LLBBERS, supra note 3, at 226-36. 
information and what we ought to do ought to reflect the outcome of that information-is going to be quite strong. ${ }^{16}$

Professor Herz concurs that this may be a problem:

What can realistically be expected of an agency dealing with a million comments, thousands of which duplicate one another? The old model of careful individual consideration is inapplicable. Unavoidably, the agency will start to do what, for example, members of Congress do: avoid the subtleties and keep a running tally with the grossest sort of division--basically "for" or "against."17

This, he cautions, may not only lead to "information overload"18 (although technology may also make it possible for agencies to efficiently sort and categorize voluminous comments), 19 it might lead to a general politicization of the rulemaking process, moving away from the technocratic model of rulemaking, where the substance of the comment is more important than who submitted it or how many times it was repeated, to a type of referendum. 20 "In short," he notes, rather disquietingly, "the

16. Peter Strauss, Comments at American University's Center for Rulemaking's ERulemaking Conference, supra note 6, at 28.

17. Michael Herz, Rulemaking, in Developments in Administrative LaW AND Regulatory Practice 2002-2003, at 129, 148-49 (Jeffrey S. Lubbers ed., 2004). He also points out, "There is one important caveat, however. To the extent that the comments are duplicative, the burden of responding is not increased." Id. at 149 n.78.

18. Id. at 149; see also Randolph J. May, Under Pressure: Campaign-Style Tactics Are the Wrong Way to Influence Agency Decisions, Legal Times, July 7, 2003, at 44 (referring to a mass e-mail, post card, and call-in campaign which resulted in the Federal Communications Commission receiving 750,000 e-mails in response to a deregulatory initiative and rulemaking); Jim Rossi, Participation Run Amok: The Costs of Mass Participation for Deliberative Agency Decisionmaking, 92 Nw. U. L. Rev. 173, 224-28 (1997) (maintaining that although increased participation can result in greater amounts of information available to decisionmakers and participants, this may lead agency decisionmakers to "miss the forest for the trees").

19. See Professor Stuart Shulman, Univ. of Pittsburgh, Comments at American University's Center for the Study of Rulemaking, Panel 4: Participation in Rulemaking 15 (Mar. 16, 2005), http://www.american.edu/academic.depts/provost/rulemaking/

transcripts.pdf ("Part of what we're doing with the computer scientists is developing tools for dealing with this information flood, and we're making some progress ... where we'll be able to deliver a tool to agency personnel who want to identify [as] quickly as possible those clusters of duplicate and near-duplicate e-mails."). For a technical paper describing these promising techniques for sorting comments, see Hui Yang \& Jamie Callan, Near-Duplicate Detection for eRulemaking, in Proceedings of THE SixTH National Conference on Digital GOVERNMENT RESEARCH http://erulemaking.ucsur.pitt.edu/doc/papers/dgo05-huiyang.pdf.

20. Professor Herz points to the example of the "roadless rule," a heavily litigated rule issued in the waning days of the Clinton Administration, which attempted to restrict road construction in large parts of Forest Service land:

The rule has generated a number of legal challenges, with several district judges 
new technology is forcing agencies toward a particular model of the process and function of rulemaking, as opposed to enabling agencies to better function under the model chosen independent of that technology."21 Other researchers have found a proliferation of "form comments,"22 making Professor Noveck's concern about the use of robot programs to generate "notice and spam" all the more disquieting. ${ }^{23}$

\section{The SuRVEY}

To find out how the advent of e-rulemaking is perceived among federal rulemakers, I designed and distributed a survey to rulemakers, using an electronic survey program. ${ }^{24}$ After designing the questions with helpful constructive criticism from Professor Peter Strauss and a very experienced rulemaking supervisor from the U.S. Department of Transportation, Neil Eisner, I circulated it to Mr. Eisner and other such supervisors and asked that they encourage their rulemaking staffers to take this survey.

The survey is intended to be exploratory. As such, I used a combination of convenience and snowball sampling because the desired sample characteristics (in this case federal rulemakers who use e-rulemaking) are not that numerous or identifiable and not easy to access. I relied primarily

finding defects in the process, and the Bush Administration is considering diluting its protections in Alaska. Comments on the proposed rule and/or the Draft EIS, and on the current Alaska proposals, numbered in the millions and have been overwhelmingly in favor of stringent protections. Press coverage has overwhelmingly treated the comment process as a sort of vote. This conception can'also be seen in an amicus brief submitted to the Ninth Circuit in Kootenai Tribe by the Montana Attorney General. The brief's basic point had nothing to do with legality, but came down to this: "Hey, Montanans overwhelmingly support this rule, as shown by tabulating our comments during the process." Emphasizing that 67 percent of commenters in Montana (and 96 percent nationwide) favored stronger protections than were anticipated in the Draft EIS, and that the Forest Service responded by strengthening protections, the brief concludes that the rule is "the product of public rulemaking at its most effective." What's more, the Ninth Circuit placed some weight on this argument.

Herz, supra note 17 , at 150-51 (footnotes omitted).

21. Id. at 151 .

22. See David Schlosberg, Stephen Zavetoski \& Stuart Shulman, To Submit a Form or Not to Submit a Form, That is the (Real) Question: Deliberation and Mass Participation in U.S. Regulatory Rulemaking (May 5, 2005) (unpublished manuscript), http://erulemaking.ucsur.pitt.edu/doc/papers/SDEST_stanford_precon.pdf (finding significant differences between respondents who submitted original comments and those who submitted form letters). For more such research, visit the website of the e-rulemaking group at the University of Pittsburgh, http://erulemaking.ucsur.pitt.edu.

23. Noveck, supra note 3 , at 441 .

24. I used Survey Monkey (professional subscription), www.surveymonkey.com. 
on referrals from the federal rulemaking supervisors. ${ }^{25}$ Thus, the sample is small and results may not be completely representative of the e-rulemaking population. Nonetheless, the survey of federal rulemakers is the first of its kind on this topic and does provides some insights and early indications of the attitudes and perceptions of those on the "firing line" of this new technology.

After a little more than a month of collecting responses, I had amassed seventy-four responses from a wide variety of agencies. The breakdown was as follows: ${ }^{26}$

\begin{tabular}{|l|l|}
\hline Agency & No. of Responses \\
\hline Department of Transportation (DOT) & 17 \\
\hline Department of Homeland Security (DHS) & 12 \\
\hline Environmental Protection Agency (EPA) & 8 \\
\hline Department of Labor (DOL) & 8 \\
\hline Department of the Treasury (Treasury) & 7 \\
\hline Department of Energy (DOE) & 5 \\
\hline Department of Veterans Affairs (DVA) & 4 \\
\hline Department of Commerce (DOC) & 2 \\
\hline Department of the Interior (DOI) & 2 \\
\hline $\begin{array}{l}\text { Department of Health \& Human Services } \\
\text { HHS) }\end{array}$ & 1 \\
\hline $\begin{array}{l}\text { Department of Housing \& Urban Development } \\
\text { (HUD) }\end{array}$ & 1 \\
\hline Federal Communications Commission (FCC) & 1 \\
\hline Federal Election Commission (FEC) & 1 \\
\hline Unidentified & 4 \\
\hline
\end{tabular}

A large majority of the respondents spent most of their work time on rulemaking activities:

25. Neil Eisner periodically convenes a "brown bag lunch group" of his peers from other agencies. I circulated an e-mail to each of them with the survey link and asked for their help in circulating it to their staffs. I also used the Federal Yellow Book to look for other such supervisors and sent e-mails to those that I found. Finally, I attended a conference of agency rulemakers and solicited their cooperation.

26. Some respondents also mentioned their subagencies. For example, five of the Department of Transportation's respondents were from the Federal Aviation Administration, and five were from other different subagencies. Five of the Department of Homeland Security's respondents were from the Coast Guard, and three from the Transportation Safety Administration. 


\begin{tabular}{|l|l|}
\hline Percentage of Time & No. of Respondents \\
\hline $100 \%$ & 20 \\
\hline $90-99 \%$ & 17 \\
\hline $75-89 \%$ & 14 \\
\hline $50-74 \%$ & 9 \\
\hline $25-49 \%$ & 7 \\
\hline $10-24 \%$ & 5 \\
\hline $5 \%$ & 1 \\
\hline No answer & 1 \\
\hline
\end{tabular}

About three-fifths of the respondents described themselves as "more of a line employee" $(n=45)$ and two-fifths as more of a "supervisor" $(n=29)$.

Most were attorneys:

\begin{tabular}{|l|l|}
\hline Position & No. of Respondents \\
\hline Attorney & 47 \\
\hline Policy Expert in the Field & 8 \\
\hline Technical Expert in the Field & 5 \\
\hline Economist & 2 \\
\hline Political Scientist & 1 \\
\hline Other & 11 \\
\hline
\end{tabular}

The "other" category included four "regulations analysts," including one with a J.D. degree; two "writer-editors"; two "IT"; one "project manager"; and one with a "varicd" background.

The age of the respondents skewed rather high:

\begin{tabular}{|l|l|}
\hline Age Range & No. of Respondents \\
\hline Below 30 & 7 \\
\hline $30-39$ & 14 \\
\hline $40-49$ & 21 \\
\hline $50-59$ & 22 \\
\hline Above 60 & 10 \\
\hline
\end{tabular}

Rulemaking experience was also correspondingly high, but was well distributed:

\begin{tabular}{|l|l|}
\hline Years of Experience & No. of Respondents \\
\hline $0-2$ & 12 \\
\hline $3-5$ & 11 \\
\hline $5-10$ & 18 \\
\hline
\end{tabular}




\begin{tabular}{|l|l|}
\hline $10-20$ & 16 \\
\hline $20+$ & 17 \\
\hline
\end{tabular}

Most of the respondents had worked with rulemaking both before and after the advent of e-rulemaking (forty-seven), although eleven had worked only with the new system. (Fifteen skipped this question and one had not worked at all with e-rulemaking.) Some of the questions discussed below were only asked of those that had worked before and after.

\section{A. Positive Effects of e-Rulemaking (from the Rulemakers' Perspective)}

I asked a series of sixteen questions attempting to see whether erulemaking has made it more or less easy to undertake some positive rulemaking activities: "When compared to the old system of paper comments, has the advent of e-rulemaking made it more difficult or easier for your agency to do the following."

I used a seven-point range: (1) Much more difficult under the new system; (2) More difficult under the new system; (3) A little more difficult under the new system; (4) The same as under the old system; (5) A little easier under the new system; (6) Easier under the new system; (7) Much easier under the new system. I also allowed an $\mathcal{N} / A$ answer ("Insufficient experience with this issue").

Sixty-four of the seventy-four respondents answered this long question, although some of those (including presumably those that had not worked with both systems) answered $\mathcal{N} / A$ for many of them. But all but two of the sixteen questions elicited at least thirty-six ranked answers.

Question 1: When compared to the old system of paper comments, has the advent of $e^{-}$ rulemaking made it more difficult or easier for your agency to do the following?

a. Conduct proactive notification and outreach to the public by maintaining target mailing lists (or listseros) of people who are interested in selected aspects of your rulemaking agendas?

\begin{tabular}{|l|l|l|l|}
\hline $\begin{array}{l}\text { Answer } \\
\text { No. }\end{array}$ & $\begin{array}{l}\text { Corresponding } \\
\text { Written Answer }\end{array}$ & $\begin{array}{l}\text { No. of } \\
\text { Respondents }\end{array}$ & Percentage \\
\hline 1 & $\begin{array}{l}\text { Much more difficult under } \\
\text { the new system }\end{array}$ & 0 & $0 \%$ \\
\hline 2 & $\begin{array}{l}\text { More difficult under the } \\
\text { new system }\end{array}$ & 0 & $0 \%$ \\
\hline 3 & $\begin{array}{l}\text { A little more difficult } \\
\text { under the new system }\end{array}$ & 1 & $3 \%$ \\
\hline
\end{tabular}




\begin{tabular}{|l|l|l|l|}
\hline 4 & $\begin{array}{l}\text { The same as under the old } \\
\text { system }\end{array}$ & 11 & $30 \%$ \\
\hline 5 & $\begin{array}{l}\text { A little easier under the } \\
\text { new system }\end{array}$ & 3 & $8 \%$ \\
\hline 6 & $\begin{array}{l}\text { Easier under the new } \\
\text { system }\end{array}$ & 12 & $32 \%$ \\
\hline 7 & $\begin{array}{l}\text { Much easier under the } \\
\text { new system }\end{array}$ & 10 & $27 \%$ \\
\hline & N/A & 27 & \\
\hline
\end{tabular}

Response Count: 64

Average Score: $5.51(n=37)$

Thus, only one respondent answered that it was harder to undertake targeted outreach under the e-rulemaking system and twenty-five said it was easier to some degree. The average score on this question was a high 5.51 .

To save space, the full results for the remaining subparts of Question 1 are contained in the Appendix; here are the summary results:

\begin{tabular}{|l|l|}
\hline Question & $\begin{array}{l}\text { Average } \\
\text { Score }\end{array}$ \\
\hline b. Identify and find appropriate stakeholders? & $4.81(\mathrm{n}=42)$ \\
\hline $\begin{array}{l}\text { c. Disseminate information relevant to the agency's } \\
\text { proposed rulemaking (e.g., studies, economic analyses, } \\
\text { legal analyses), so as to generate more informed } \\
\text { commenters? }\end{array}$ & $5.67(\mathrm{n}=46)$ \\
\hline $\begin{array}{l}\text { d. Present to the public competing or multiple } \\
\text { alternatives to the proposed rules? }\end{array}$ & $4.73(\mathrm{n}=37)$ \\
\hline e. Stimulate public comments generally? & $5.33(\mathrm{n}=51)$ \\
\hline f. Sort and analyze public comments generally? & $5.02(\mathrm{n}=51)$ \\
\hline $\begin{array}{l}\text { g. Obtain public comments specifically addressed to } \\
\text { particular portions or segments of the proposed rule? }\end{array}$ & $4.64(\mathrm{n}=47)$ \\
\hline $\begin{array}{l}\text { h. Sort and analyze public comments specifically } \\
\text { addressed to particular portions or segments of the } \\
\text { proposed rule? }\end{array}$ & $4.70(\mathrm{n}=46)$ \\
\hline i. Use the concept of "reply comments"? & $5.44(\mathrm{n}=25)$ \\
\hline $\begin{array}{l}\text { j. Place summaries of ex parte communications in the } \\
\text { record more quickly? }\end{array}$ & $5.16(\mathrm{n}=38)$ \\
\hline
\end{tabular}




\begin{tabular}{|l|l|}
\hline $\begin{array}{l}\text { k. Coordinate the rulemaking internally by allowing } \\
\text { many people to look at the same rulemaking docket } \\
\text { without getting in each others' way? }\end{array}$ & $5.70(\mathrm{n}=43)$ \\
\hline $\begin{array}{l}\text { 1. Coordinate the rulemaking externally with O[ffice of] } \\
\text { M[anagement and] B[udget] or other interested } \\
\text { government entities? }\end{array}$ & $5.23(\mathrm{n}=40)$ \\
\hline $\begin{array}{l}\text { m. Conduct interactive proceedings in rulemaking, such } \\
\text { as "negotiated rulemaking"? }\end{array}$ & $4.19(\mathrm{n}=16)$ \\
\hline $\begin{array}{l}\text { n. Craft a preamble to the final rule that responds to } \\
\text { comments and includes all relevant studies and analyses? }\end{array}$ & $5.05(\mathrm{n}=44)$ \\
\hline $\begin{array}{l}\text { o. Develop and implement appropriate archival practices } \\
\text { relating to rulemakings (such as retiring records, etc.)? }\end{array}$ & $5.25(\mathrm{n}=36)$ \\
\hline $\begin{array}{l}\text { p. Periodically evaluate and review the rule (and related } \\
\text { rules), once promulgated? }\end{array}$ & $5.19(\mathrm{n}=37)$ \\
\hline
\end{tabular}

Significantly, after tabulating an average of the ranked answers for each of the sixteen questions, all of them exceeded " 4 " " "same as under the old system") and twelve of them exceeded " 5. " This means that the advent of e-rulemaking has been "positive" for each activity. The activities with the highest average scores were "Coordinate the rulemaking internally by allowing many people to look at the same rulemaking docket without getting in each others' way" (5.70), and two activities dealing with "proactive notification and outreach" (5.51) and information dissemination (5.67). The four questions that led to only mildly positive responses were those relating to negotiated rulemaking (4.19), obtaining comments on segments of the rule (4.64), sorting such comments (4.70), and identifying and finding stakeholders (4.73).

\section{B. Worrisome Effects of e-Rulemaking (from the Rulemakers' Perspective)}

Using a similar seven-point scale, I then asked a series of ten questions attempting to see whether e-rulemaking has indeed increased the level of concern about some of the worries mentioned above. All but one of the ten questions elicited at least thirty-six ranked answers.

Question 2. When compared to the old system of paper comments, has the advent of $e^{-}$ rulemaking caused your agency to worry more or less about the following: 
a. Outside intervention ("hacking") into your rulemaking proceedings?

\begin{tabular}{|c|c|c|c|}
\hline $\begin{array}{l}\text { Answer } \\
\text { No. }\end{array}$ & $\begin{array}{l}\text { Corresponding } \\
\text { Written Answer }\end{array}$ & $\begin{array}{l}\text { No. of } \\
\text { Respondents }\end{array}$ & Percentage \\
\hline 1 & $\begin{array}{l}\text { Worry much more } \\
\text { under the new } \\
\text { system }\end{array}$ & 3 & $8 \%$ \\
\hline 2 & $\begin{array}{l}\text { Worry more under } \\
\text { the new system }\end{array}$ & 9 & $24 \%$ \\
\hline 3 & $\begin{array}{l}\text { Worry a little more } \\
\text { under the new } \\
\text { system }\end{array}$ & 12 & $32 \%$ \\
\hline 4 & $\begin{array}{l}\text { The same as under } \\
\text { the old system }\end{array}$ & 7 & $19 \%$ \\
\hline 5 & $\begin{array}{l}\text { Worry a little less } \\
\text { under the new } \\
\text { system }\end{array}$ & 1 & $3 \%$ \\
\hline 6 & $\begin{array}{l}\text { Worry less under } \\
\text { the new system }\end{array}$ & 2 & $5 \%$ \\
\hline \multirow[t]{2}{*}{7} & $\begin{array}{l}\text { Worry much less } \\
\text { under the new } \\
\text { system }\end{array}$ & 3 & $8 \%$ \\
\hline & $\mathrm{N} / \mathrm{A}$ & 25 & \\
\hline
\end{tabular}

Response Count: 62

Average score: $3.32(n=37)$

Thus, only six respondents answered that they were less worried about hacking in the new system and twenty-four worried more to some degree. The average score on this question was a low 3.32.

Again, for brevity's sake, the full results for the remaining subparts of Question 2 are contained in the Appendix; here are the summary results:

\begin{tabular}{|l|l|}
\hline Question & Average Score \\
\hline $\begin{array}{l}\text { b. Acquiring viruses via attachments submitted in } \\
\text { comments? }\end{array}$ & $3.31(\mathrm{n}=36)$ \\
\hline $\begin{array}{l}\text { c. Inappropriate exposure of materials in the } \\
\text { rulemaking docket that might contain confidential } \\
\text { business information? }\end{array}$ & $3.11(\mathrm{n}=45)$ \\
\hline
\end{tabular}




\begin{tabular}{|l|l|}
\hline $\begin{array}{l}\text { d. Inappropriate exposure of materials in the } \\
\text { rulemaking docket that might contain copyrighted } \\
\text { materials? }\end{array}$ & $3.20(\mathrm{n}=46)$ \\
\hline $\begin{array}{l}\text { e. Inappropriate exposure of materials in the } \\
\text { rulemaking docket that might contain indecent or } \\
\text { obscene language or materials? }\end{array}$ & $3.30(\mathrm{n}=44)$ \\
\hline $\begin{array}{l}\text { f. Inappropriate exposure of information in the } \\
\text { rulemaking docket that might lead to national } \\
\text { security problems? }\end{array}$ & $3.82(\mathrm{n}=28)$ \\
\hline $\begin{array}{l}\text { g. Risk of information destruction or other } \\
\text { irretrievable loss of rulemaking information? }\end{array}$ & $4.09(\mathrm{n}=43)$ \\
\hline $\begin{array}{l}\text { h. Integrating (scanned) paper comments with e- } \\
\text { mailed or electronically submitted comments? }\end{array}$ & $4.14(\mathrm{n}=49)$ \\
\hline i. The authenticity of comments? & $3.81(\mathrm{n}=47)$ \\
\hline $\begin{array}{l}\text { j. Ensuring the protection of the privacy of } \\
\text { commenters? }\end{array}$ & $3.13(\mathrm{n}=46)$ \\
\hline
\end{tabular}

After tabulating an average of the ranked answers for each of the ten questions, eight of them were below "4" ("same as under the old system") meaning that the advent of e-rulemaking has produced some heightened worries. The greatest worries (lowest average scores) concerned "Inappropriate exposure of materials in the rulemaking docket that might contain confidential business information" (3.11), "Ensuring the protection of the privacy of commenters" (3.13), "Inappropriate exposure of materials in the rulemaking docket that might contain copyrighted materials" (3.20), and "Inappropriate exposure of materials in the rulemaking docket that might contain indecent or obscene language or materials" (3.30). It should be noted that attorney respondents were even more worried about these last four categories $(3.00,2.90,3.03,3.25)$.

Only two of the hypothesized concerns were less worrisome under the erulemaking system: "Integrating (scanned) paper comments with e-mailed or electronically submitted comments?" (4.14) and "Risk of informationdestruction or other irretrievable loss of rulemaking information?" (4.09).

\section{Other Effects of e-Rulemaking (from the Rulemakers' Perspective)}

The following questions were to be answered only by those forty-seven respondents who had indicated that they had worked with rulemaking both before and after the advent of e-rulemaking. (Those that had not were directed to skip these questions.) As the number of respondents for these answers varied only from forty-nine to fifty, it appears that this direction 
was followed assiduously. ${ }^{27}$ The survey advised respondents: "This and questions 3-11 may be difficult to answer with great certainty. Please provide your impressions as one who has been involved in rulemaking both before and after e-rulemaking."

An important issue is whether e-rulemaking has led to an increase in public comments. Only one respondent reported fewer comments, thirteen reported the same, while thirty-one reported some level of increase. The average "score" among those who provided a ranking was a high 5.36 out of 7 .

\section{Number of comments?}

\begin{tabular}{|l|l|l|}
\hline Response & No. of Respondents & Percentage of Total \\
\hline Many Fewer & 0 & $0 \%$ \\
\hline Fewer & 1 & $2 \%$ \\
\hline Slightly Fewer & 0 & $0 \%$ \\
\hline The same & 13 & $26 \%$ \\
\hline Slightly More & 9 & $18 \%$ \\
\hline More & 12 & $24 \%$ \\
\hline Many More & 10 & $20 \%$ \\
\hline Don't Know & 5 & $10 \%$ \\
\hline
\end{tabular}

Response Count: 50

Average Score: $5.36(n=45)$

What about the usefulness of the comments? The responses on whether the advent of e-rulemaking has led to more or fewer comments "that provide new useful information or arguments" led to a split decision. The average of the rankings here was 3.8 (or close to "the same"). Three-fifths of the respondents indicated no difference in this respect.

\section{Comments with new useful information or arguments?}

\begin{tabular}{|l|l|l|}
\hline Response & No. of Respondents & Percentage of Total \\
\hline Many Fewer & 2 & $4 \%$ \\
\hline Fewer & 5 & $10 \%$ \\
\hline Slightly Fewer & 1 & $2 \%$ \\
\hline
\end{tabular}

27. Note that it is possible that a few of those who had skipped the indicator question might have nonetheless answered some of the follow-up questions. On the other hand, a number answered each question "Don't know." 


\begin{tabular}{|l|l|l|}
\hline The Same & 30 & $60 \%$ \\
\hline Slightly More & 4 & $8 \%$ \\
\hline More & 2 & $4 \%$ \\
\hline Many More & 0 & $0 \%$ \\
\hline Don't Know & 6 & $12 \%$ \\
\hline
\end{tabular}

Response Count: 50

Average Score: $3.80(n=44)$

Not only was e-rulemaking perceived by many as not generating more useful comments, it was also strongly perceived to generate more comments "that provide only opinions without supporting facts or arguments." No one reported fewer such comments while twenty-five respondents reported an increase.

4. Comments that only provide opinions without supporting facts or arguments?

\begin{tabular}{|l|l|l|}
\hline Response & No. of Respondents & Percentage of Total \\
\hline Many More & 10 & $20 \%$ \\
\hline More & 5 & $10 \%$ \\
\hline Slightly More & 10 & $20 \%$ \\
\hline The Same & 17 & $34 \%$ \\
\hline Slightly Fewer & 0 & $0 \%$ \\
\hline Fewer & 0 & $0 \%$ \\
\hline Many Fewer & 0 & $0 \%$ \\
\hline Don't Know & 8 & $16 \%$ \\
\hline
\end{tabular}

Response Count: 50

Average Score: $2.81(\mathrm{n}=42)$

Even more telling is the high number of people who reported an increase in the number of comments that "are identical or nearly identical." Twenty reported an increase, with thirteen of these answering "many more." Only one respondent reported fewer such comments.

5. Comments that are identical or nearly identical?

\begin{tabular}{|l|l|l|}
\hline Response & No. of Respondents & Percentage of Total \\
\hline Many More & 13 & $26.5 \%$ \\
\hline More & 7 & $14.3 \%$ \\
\hline Slightly More & 4 & $8.2 \%$ \\
\hline
\end{tabular}




\begin{tabular}{|l|l|l|}
\hline The Same & 14 & $28.6 \%$ \\
\hline Slightly Fewer & 0 & $0 \%$ \\
\hline Fewer & 1 & $2 \%$ \\
\hline Many Fewer & 0 & $0 \%$ \\
\hline Don't Know & 10 & $20.4 \%$ \\
\hline
\end{tabular}

Response Count: 49

Average Score: $2.59(n=39)$

Despite this tendency toward more opinionated and more similar comments, most rulemakers nonetheless reported that e-rulemaking has not caused them to place less "value on the comments by the average citizen." Three-fourths of the respondents answered "the same" for this question.

6. Value of the comments of average citizens?

\begin{tabular}{|l|l|l|}
\hline Response & No. of Respondents & Percentage of Total \\
\hline Much Less & 1 & $2 \%$ \\
\hline Less & 3 & $6 \%$ \\
\hline Slightly Less & 3 & $6 \%$ \\
\hline The Same & 38 & $76 \%$ \\
\hline Slightly Higher & 0 & $0 \%$ \\
\hline Higher & 2 & $4 \%$ \\
\hline Much Higher & 3 & $6 \%$ \\
\hline
\end{tabular}

Response Count: 50

Average Score: $4.27(n=50)$

Does e-rulemaking perhaps lead to more commenters responding to others' comments or to economic analyses in the docket? One might hypothesize that this would be the case since such comments and analyses are easier to access online by potential commenters. There is at least some indication that this is occurring, especially with respect to reacting to others' comments.

7. In your experience, with the advent of $e$-rulemaking, have you seen more commenters responding to comments already in the docket?

\begin{tabular}{|l|l|}
\hline Response & No. of Respondents \\
\hline Yes & 20 \\
\hline No & 16 \\
\hline
\end{tabular}




\begin{tabular}{|l|l|}
\hline Don't Know & 14 \\
\hline
\end{tabular}

8. In your experience, with the advent of e-rulemaking, have commenters made more references to economic analyses and other supporting documents in the docket?

\begin{tabular}{|l|l|}
\hline Response & No. of Respondents \\
\hline Yes & 7 \\
\hline No & 22 \\
\hline Don't Know & 20 \\
\hline
\end{tabular}

E-rulemaking has also led to a slight increase in the number of questions agencies receive about ongoing rulemakings.

9. Number of questions to your office about ongoing rulemakings?

\begin{tabular}{|l|l|l|}
\hline Response & No. of Respondents & Percentage of Total \\
\hline Many Fewer & 0 & $0 \%$ \\
\hline Fewer & 4 & $8 \%$ \\
\hline Slightly Fewer & 2 & $4 \%$ \\
\hline The Same & 22 & $44 \%$ \\
\hline Slightly More & 5 & $10 \%$ \\
\hline More & 5 & $10 \%$ \\
\hline Many More & 1 & $2 \%$ \\
\hline Don't Know & 11 & $22 \%$ \\
\hline
\end{tabular}

Response Count: 50

Average Score: $4.21(\mathrm{n}=39)$

Most agency rulemakers reported some opportunity to consult with and learn from their counterparts in other agencies about e-rulemaking issues, but more than half reported that this opportunity was less than adequate.

10. As an agency rulemaker, how much opportunity have you had to consult with and learm from your counterparts in other agencies about e-rulemaking issues?

\begin{tabular}{|l|l|l|}
\hline Response & No. of Respondents & Percentage of Total \\
\hline None & 8 & $13.5 \%$ \\
\hline Minimal Opportunity & 25 & $42.3 \%$ \\
\hline Adequate Opportunity & 18 & $30.5 \%$ \\
\hline Great Opportunity & 8 & $13.5 \%$ \\
\hline
\end{tabular}


A few narrative responses were received to this question. Several commenters lauded the efforts of some agencies (e.g., EPA, Treasury) to conduct workshops and share information, but others wished for more: "Simply not enough."; "I hope there will be many more opportunities in the future."; "I believe that in general we do a terrible job of facilitating the exchange of knowledge, best practices, and lessons learned."; and "It would be great to have a more advanced training on the use of e-rulemaking dealing less with the mechanics."

The survey also sought to elicit information about how agencies deal with the e-comments. One question simply asked if agency rulemakers tended to make hard (paper) copies of e-comments. Of the fifty-nine responses, only eight said "never." Most (twenty-four) said "occasionally," nine said "usually," and eighteen said "always."

This question stimulated a number of narrative responses. One (from the DOL) reported, "We still legally have to keep a paper copy of all comments, once a docket closes and we post electronic comments we print them all out." Another (no agency identified) explained, "When a rulemaking results in litigation, hard copies of the administrative record (including comments) need to be made for the parties and the court. Also, if a rule is complex, requests for hard copies from within the agency are inevitable." A third had another pragmatic explanation: "It is virtually impossible to review complex or lengthy electronic comments without making a hard copy." The same goes for sharing comments with colleagues for review and consideration, particularly if those colleagues do not have access to the e-comments. Several others said something to the effect of "I will make copies of significant comments that will be used to change analysis or be responded to in [the] preamble."

Another question asked whether the respondent's agency used "computer based 'sorting' technology to help categorize (or identify duplicate) e-comments." Of the fifty-nine respondents, twenty did not know. Of those who did know, seventeen said "yes"; twenty-two said "no." Of the twelve who expressed an opinion on this, three said this technology was "very helpful," six said "helpful," two said "a little helpful," and only one said "not at all." Two respondents (from DOL and DHS) reported that their agency had hired a contractor to do this.

As to the "bottom line" questions of whether e-rulemaking helped agencies promulgate rules more efficiently or promulgate higher quality rules, the responses were encouraging. Twenty-three of forty-four respondents reported an increase in efficiency as opposed to only eight who reported a decline. 
11. In toto, and as a general matter, has the advent of e-rulemaking allowed your agency to promulgate rules less or more efficiently?

\begin{tabular}{|l|l|l|}
\hline Response & $\begin{array}{l}\text { No. of } \\
\text { Respondents }\end{array}$ & $\begin{array}{l}\text { Percentage of } \\
\text { Total }\end{array}$ \\
\hline Much Less & 1 & $2 \%$ \\
\hline Less & 6 & $12 \%$ \\
\hline Slightly Less & 1 & $2 \%$ \\
\hline The Same & 13 & $26 \%$ \\
\hline Slightly More & 7 & $14 \%$ \\
\hline More & 13 & $26 \%$ \\
\hline Much More & 3 & $6 \%$ \\
\hline Don't Know/No Opinion & 6 & $12 \%$ \\
\hline
\end{tabular}

Response Count: 50

Average Score: $4.61(n=44)$

The responses as to higher quality rules were also positive, though somewhat less so, with twelve of forty-four respondents reporting an increase in quality and five reporting a decrease. The main difference with the efficiency question is that twice as many respondents answered "the same" as to quality.

12. In toto, and as a general matter, in your opinion, has the advent of e-rulemaking made it less or more easy for your agency to promulgate higher quality rules?

\begin{tabular}{|l|l|l|}
\hline Response & $\begin{array}{l}\text { No. of } \\
\text { Respondents }\end{array}$ & Percentage of Total \\
\hline Much Less & 0 & $0 \%$ \\
\hline Less & 2 & $4 \%$ \\
\hline Slightly Less & 3 & $6 \%$ \\
\hline The Same & 27 & $54 \%$ \\
\hline Slightly More & 3 & $6 \%$ \\
\hline More & 7 & $14 \%$ \\
\hline Much More & 2 & $4 \%$ \\
\hline Don't Know/No Opinion & 6 & $12 \%$ \\
\hline
\end{tabular}

Response Count: 50

Average Score: $4.36(n=44)$ 
One factor to keep in mind concerning agency staff attitudes toward erulemaking is the increasing use of electronic dockets for other agency actions. Of the fifty-nine respondents, thirty-six reported that their agency uses e-dockets for actions other than rulemaking, and twenty-three said they did not. According to the narrative answers, agencies were using edockets for adjudication, guidances, notices, Paperwork Reduction Act notices, draft legislation, peer-reviewed matters, and certain correspondence.

One commenter waxed enthusiastic about e-dockets:

E-dockets are fantastic. Currently the Federal Transit Administration (FTA) is using an e-docket to formulate an agency policy statement. Also, FTA uses e-dockets as forms of electronic filing systems ... for various administrative adjudications, such as charter service adjudications. Complainants may file complaints electronically on an e-docket. Once a complainant files a complaint on an e-docket, the respondent may respond electronically via the e-docket. FTA posts its decisions on the e-docket. Ultimately, this process increases transparency in government, and we have not received as many FOIA requests for these documents because the documents are easily accessible.

The last question on the survey was open-ended and asked "for any other comments." Twenty-six respondents took the time to answer. The following are the most significant comments-and they tend to divide equally between favorable and unfavorable - though we should bear in mind that usually those with a grievance may be more likely to respond to such a question.

\section{Rulemakers' General Comments on e-Rulemaking}

\section{Generally Positive Comments}

(a) E-rulemaking is the obvious choice for encouraging public comment and allowing easy access to records from anywhere and without risking the loss of original hard copies. My only complaint is that the process is not completely electronic - we still generate many paper copies of each rule or proposal.

(b) Having an electronic docket has enabled me to manage comments to my rulemaking projects much more easily. I now can just tell people on my rulemaking project how to go to regulations.gov instead of having to make hard copies of the comments and distributing them to the team members on a regular basis.

(c) E-rulemaking has improved public access and internal efficiency, but we are not yet using all the potential tools that it makes available.

(d) It is a very powerful tool. We need to continue to inform the public 
on how best to use the tool. We need to continue to add the next phase to the Federal Docket Management System (FDMS), namely more rulemaking development tools for the rule writer.

(e) With more people using the Internet, it seems the right way to conduct rulemaking and promises to reach more folks who don't read the Federal Register. In addition to reaching older members of society, making the process available online makes it more likely we will reach members of Generation X and the Millennium Generation. I was informed by an IT person in a [regulations] development workshop, however, that an online rulemaking docket did not constitute a blog because you have to open the NPRM [notice of proposed rulemaking] (or other documents published in the Federal Register) to get to the core subject. But you could set up a blog with a link to the docket, webcast live public meetings[,] and record them as podcast files for downloading from the docket.

(f) Interesting topic where many questions are yet unanswered. I think at this point the benefits to the agency are not fully evident since much time is spent on learning the new systems, but hopefully in the near future it will prove more efficient than the previous paper-based system.

(g) E-rulemaking is better at letting the public know what the agencies are doing than it is at providing thoughtful input into the decisions themselves.

(h) I support it.... In addition to making agency rulemaking more accessible to the public, it makes it easy for me to check DOL and other agency rulemakings and comments. It's a great research tool.

(i) Good start but they need to further refine the process for better functionality.

(j) Makes it much easier for the public to see the comments, less work for the agency to respond to requests for copies of comments. Less likelihood that important comments will go missing due to mistake or design.

(k) E-rulemaking hasn't changed the process of rulemaking. What it has done is provide easier access to already public documents easier. That is, interested parties can get documents at their desktop rather than having to go to a docket room.

\section{Generally Negative Comments}

(a) Many of the initial fears (e.g., authenticity of comments, transmissions of viruses, etc.) have not yet come to pass, but they are a constant concern.

(b) Because of intermittent FDMS and regulations.gov system outages, we continue to maintain an in-house paper-based parallel process for managing comments. Unless the reliability of e-rulemaking-related systems increase to the point where we are comfortable enough to move away from 
paper, we will not fully realize the potential efficiencies that can be gained by moving to the electronic platform.

(c) We have been "live" with FDMS less than a year, and have had only 2 or 3 rules in the system. One rule had only one (supportive) comment, and another has had well over a thousand so far, but mostly an industrygenerated paper letter-writing campaign from individuals whose names and addresses we must type and load into FDMS, a royal pain in the neck for our tiny staff.

(d) If you work at an Agency or Bureau that doesn't do many regulations, it's difficult to remember all the technology steps that are required to post a regulation. I find myself having to relearn the process each time. That is frustrating.

(e) It's difficult to isolate the effect of e-rulemaking on the rulewriting process because as more tools become available, the pressure grows to delay decisions and rulewriting until closer to the deadline.

(f) The system is very user friendly for public commenters and very user unfriendly for government regulators. Indeed, the system design seems to thwart at every stage the efficient assembly and review of public comments. It is difficult to access the comments, print them out, sort them by topic, match up attachments with cover documents, etc. Each comment has to be downloaded or printed separately before it can be skimmed for content. When there are thousands of comments, that takes an unreasonably long time. It was much faster to take a stack of hard copy comments and page through them to sort out the duplicates and hone in on the helpful, substantive letters. Plus, they could be easily sorted, flagged, and tabbed with notes and comments. In addition, it now takes much longer for comments to work their way from the technical folks that manage the erulemaking system to the regulatory folks that actually write the regulations (which could be many people on a complex regulation). I used to get the comments within a day or two of the close of the comment period; now it can take weeks.

(g) As my agency's FDMS Administrator, I have found FDMS/regulations.gov hard to use, confusing, and not intuitive at all. I also believe that what is now regulations.gov should be integrated into the Federal Register so that the Federal Register's online version of a rulemaking document contains a hotlink directly to the regulations.gov docket and comment form for that rulemaking document.

(h) It was much easier under the former USDOT e-docket system than under the regulations.gov system. More features and ability to analyze comments better. We have had quite a few technical glitches that I guess, over time, will be ironed out. For example, I cannot directly upload documents to the docket in one of my rules. 
(i) E-rulemaking, including drafting and review of rulemaking documents[,] has resulted in reduction in the quality of the reviews and rise in inclination of reviewer to revise text to meet personal style. Overall, this affects the timing and quality of rules.

(j) I believe it is more costly to my agency because we have had to maintain two systems - our old electronic system and the FDMS.

(k) We view it as a benefit for the public, not necessarily as providing a great advantage for the agency.

\section{CONCLUSION}

It is fair to conclude, based on this relatively small sample, that agency rulemakers are generally receptive to e-rulemaking, although a common theme of their early evaluations was that the new system is a "boon for the public but a bane for the agency." Indeed, a large majority of respondents reported a general increase in rulemaking efficiency and a smaller majority reported a general increase in rulemaking quality. They said this even though they were also generally dubious about the usefulness of the resulting additional comments. In addition, a series of questions asked whether e-rulemaking has made it more or less easy to undertake some positive rulemaking activities, and in each case the answer was that it was easier.

On the other hand, another series of questions asked whether erulemaking has increased the level of concern about some of the worries hypothetically associated with e-rulemaking, and in the case of eight of them, the answer was that their worries had increased.

Thus, the early picture is still mixed-no one doubts that the new system is better at engendering more public participation, although most agency rulemakers did not report receiving a concomitant increase in useful information or arguments among the additional comments. Moreover, while rulemakers are quite impressed with the internal administrative and coordination benefits provided by the new technology, they also have heightened concerns about hacking and the potential problems of inappropriate worldwide exposure of certain information in their electronic dockets. 


\section{APPENDIX}

Question 1: When compared to the old system of paper comments, has the advent of e-rulemaking made it more difficult or easier for your agency to do the following?

a. Conduct proactive notification and outreach to the public by maintaining target mailing lists (or listservs) of people who are interested in selected aspects of your rulemaking agendas?

\begin{tabular}{|l|l|l|l|}
\hline $\begin{array}{l}\text { Answer } \\
\text { Number }\end{array}$ & $\begin{array}{l}\text { Corresponding } \\
\text { Written Answer }\end{array}$ & $\begin{array}{l}\text { No. of } \\
\text { Respondents }\end{array}$ & $\begin{array}{l}\text { Percentage of } \\
\text { Respondents }\end{array}$ \\
\hline 1 & $\begin{array}{l}\text { Much more difficult under the new } \\
\text { system }\end{array}$ & 0 & $0 \%$ \\
\hline 2 & More difficult under the new system & 0 & $0 \%$ \\
\hline 3 & $\begin{array}{l}\text { A little more difficult under the new } \\
\text { system }\end{array}$ & 1 & $3 \%$ \\
\hline 4 & The same under the new system & 11 & $30 \%$ \\
\hline 5 & A little easier under the new system & 3 & $8 \%$ \\
\hline 6 & Easier under the new system & 12 & $32 \%$ \\
\hline 7 & Much easier under the new system & 10 & $27 \%$ \\
\hline & N/A & 27 & \\
\hline
\end{tabular}

Response Count: 64

Average Score: $5.51 \quad(\mathrm{n}=37)$

\section{b. Identify and find appropriate stakeholders?}

\begin{tabular}{|l|l|l|l|}
\hline $\begin{array}{l}\text { Answer } \\
\text { Number }\end{array}$ & $\begin{array}{l}\text { Corresponding } \\
\text { Written Answer }\end{array}$ & $\begin{array}{l}\text { No. of } \\
\text { Respondents }\end{array}$ & $\begin{array}{l}\text { Percentage of } \\
\text { Respondents }\end{array}$ \\
\hline 1 & $\begin{array}{l}\text { Much more difficult under the new } \\
\text { system }\end{array}$ & 0 & $0 \%$ \\
\hline 2 & More difficult under the new system & 1 & $2 \%$ \\
\hline 3 & $\begin{array}{l}\text { A little more difficult under the new } \\
\text { system }\end{array}$ & 3 & $7 \%$ \\
\hline 4 & The same under the new system & 16 & $38 \%$ \\
\hline 5 & A little easier under the new system & 9 & $21 \%$ \\
\hline 6 & Easier under the new system & 9 & $21 \%$ \\
\hline 7 & Much easier under the new system & 4 & $10 \%$ \\
\hline & N/A & 22 & \\
\hline
\end{tabular}

Response Count: 64

Average Score: $4.81(n=42)$ 
c. Disseminate information relevant to the agency's proposed rulemaking (e.g., studies, economic analyses, legal analyses), so as to generate more informed commenters?

\begin{tabular}{|l|l|l|l|}
\hline $\begin{array}{l}\text { Answer } \\
\text { Number }\end{array}$ & $\begin{array}{l}\text { Corresponding } \\
\text { Written Answer }\end{array}$ & $\begin{array}{l}\text { No. of } \\
\text { Respondents }\end{array}$ & $\begin{array}{l}\text { Percentage of } \\
\text { Respondents }\end{array}$ \\
\hline 1 & $\begin{array}{l}\text { Much more difficult under the new } \\
\text { system }\end{array}$ & 0 & $0 \%$ \\
\hline 2 & More difficult under the new system & 0 & $0 \%$ \\
\hline 3 & $\begin{array}{l}\text { A little more difficult under the new } \\
\text { system }\end{array}$ & 2 & $4 \%$ \\
\hline 4 & The same under the new system & 10 & $22 \%$ \\
\hline 5 & A little easier under the new system & 5 & $11 \%$ \\
\hline 6 & Easier under the new system & 13 & $28 \%$ \\
\hline 7 & Much easier under the new system & 16 & $35 \%$ \\
\hline & N/A & 18 & \\
\hline
\end{tabular}

Response Count: 64

Average Score: $5.67(n=46)$

d. Present to the public competing or multiple alternatives to the proposed rules?

\begin{tabular}{|l|l|l|l|}
\hline $\begin{array}{l}\text { Answer } \\
\text { Number }\end{array}$ & $\begin{array}{l}\text { Corresponding } \\
\text { Written Answer }\end{array}$ & $\begin{array}{l}\text { No. of } \\
\text { Respondents }\end{array}$ & $\begin{array}{l}\text { Percentage of } \\
\text { Respondents }\end{array}$ \\
\hline 1 & $\begin{array}{l}\text { Much more difficult under the new } \\
\text { system }\end{array}$ & 0 & $0 \%$ \\
\hline 2 & More difficult under the new system & 0 & $0 \%$ \\
\hline 3 & $\begin{array}{l}\text { A little more difficult under the new } \\
\text { system }\end{array}$ & 1 & $3 \%$ \\
\hline 4 & The same under the new system & 22 & $59 \%$ \\
\hline 5 & A little easier under the new system & 5 & $14 \%$ \\
\hline 6 & Easier under the new system & 3 & $8 \%$ \\
\hline 7 & Much easier under the new system & 6 & $\mathbf{1 6 \%}$ \\
\hline & N/A & 26 & \\
\hline
\end{tabular}

Response Count: 63

Average score: $4.73(n=37)$

e. Stimulate public comments generally?

\begin{tabular}{|l|l|l|l|}
\hline $\begin{array}{l}\text { Answer } \\
\text { Number }\end{array}$ & $\begin{array}{l}\text { Corresponding } \\
\text { Written Answer }\end{array}$ & $\begin{array}{l}\text { No. of } \\
\text { Respondents }\end{array}$ & $\begin{array}{l}\text { Percentage of } \\
\text { Respondents }\end{array}$ \\
\hline 1 & $\begin{array}{l}\text { Much more difficult under the new } \\
\text { system }\end{array}$ & 0 & $0 \%$ \\
\hline
\end{tabular}




\begin{tabular}{|l|l|l|l|}
\hline 2 & More difficult under the new system & 2 & $4 \%$ \\
\hline 3 & $\begin{array}{l}\text { A little more difficult under the new } \\
\text { system }\end{array}$ & 0 & $0 \%$ \\
\hline 4 & The same under the new system & 17 & $33 \%$ \\
\hline 5 & A little easier under the new system & 5 & $10 \%$ \\
\hline 6 & Easier under the new system & 14 & $27 \%$ \\
\hline 7 & Much easier under the new system & 13 & $25 \%$ \\
\hline & N/A & 13 & \\
\hline
\end{tabular}

Response Count: 64

Average score: $5.33(n=51)$

f. Sort and analyze public comments generally?

\begin{tabular}{|l|l|l|l|}
\hline $\begin{array}{l}\text { Answer } \\
\text { Number }\end{array}$ & $\begin{array}{l}\text { Corresponding } \\
\text { Written Answer }\end{array}$ & $\begin{array}{l}\text { No. of } \\
\text { Respondents }\end{array}$ & $\begin{array}{l}\text { Percentage of } \\
\text { Respondents }\end{array}$ \\
\hline 1 & $\begin{array}{l}\text { Much more difficult under the new } \\
\text { system }\end{array}$ & 4 & $8 \%$ \\
\hline 2 & More difficult under the new system & 2 & $4 \%$ \\
\hline 3 & $\begin{array}{l}\text { A little more difficult under the new } \\
\text { system }\end{array}$ & 2 & $4 \%$ \\
\hline 4 & The same under the new system & 12 & $24 \%$ \\
\hline 5 & A little easier under the new system & 5 & $10 \%$ \\
\hline 6 & Easier under the new system & 13 & $25 \%$ \\
\hline 7 & Much easier under the new system & 13 & $25 \%$ \\
\hline & N/A & 13 & \\
\hline
\end{tabular}

Response Count: 64

Average score: $5.02(n=51)$

g. Obtain public comments specifically addressed to particular portions or segments of the proposed rule?

\begin{tabular}{|l|l|l|l|}
\hline $\begin{array}{l}\text { Answer } \\
\text { Number }\end{array}$ & $\begin{array}{l}\text { Corresponding } \\
\text { Written Answer }\end{array}$ & $\begin{array}{l}\text { No. of } \\
\text { Respondents }\end{array}$ & $\begin{array}{l}\text { Percentage of } \\
\text { Respondents }\end{array}$ \\
\hline 1 & $\begin{array}{l}\text { Much more difficult under the new } \\
\text { system }\end{array}$ & 0 & $0 \%$ \\
\hline 2 & More difficult under the new system & 0 & $0 \%$ \\
\hline 3 & $\begin{array}{l}\text { A little more difficult under the new } \\
\text { system }\end{array}$ & 7 & $15 \%$ \\
\hline 4 & The same under the new system & 21 & $45 \%$ \\
\hline 5 & A little easier under the new system & 4 & $8 \%$ \\
\hline 6 & Easier under the new system & 12 & $26 \%$ \\
\hline
\end{tabular}




\begin{tabular}{|l|l|l|l|}
\hline 7 & Much easier under the new system & 3 & $6 \%$ \\
\hline & N/A & 17 & \\
\hline
\end{tabular}

Response Count: 64

Average score: $4.64(n=47)$

h. Sort and analyze public comments specifically addressed to particular portions or segments of the proposed rule?

\begin{tabular}{|l|l|l|l|}
\hline $\begin{array}{l}\text { Answer } \\
\text { Number }\end{array}$ & $\begin{array}{l}\text { Corresponding } \\
\text { Written Answer }\end{array}$ & $\begin{array}{l}\text { No. of } \\
\text { Respondents }\end{array}$ & $\begin{array}{l}\text { Percentage of } \\
\text { Respondents }\end{array}$ \\
\hline 1 & $\begin{array}{l}\text { Much more difficult under the new } \\
\text { system }\end{array}$ & 4 & $9 \%$ \\
\hline 2 & More difficult under the new system & 1 & $2 \%$ \\
\hline 3 & $\begin{array}{l}\text { A little more difficult under the new } \\
\text { system }\end{array}$ & 4 & $9 \%$ \\
\hline 4 & The same under the new system & 15 & $33 \%$ \\
\hline 5 & A little easier under the new system & 4 & $9 \%$ \\
\hline 6 & Easier under the new system & 10 & $22 \%$ \\
\hline 7 & Much easier under the new system & 8 & $17 \%$ \\
\hline & N/A & 18 & \\
\hline
\end{tabular}

Response Count: 64

Average score: $4.70(n=46)$

i. Use the concept of "reply comments"?

\begin{tabular}{|l|l|l|l|}
\hline $\begin{array}{l}\text { Answer } \\
\text { Number }\end{array}$ & $\begin{array}{l}\text { Corresponding } \\
\text { Written Answer }\end{array}$ & $\begin{array}{l}\text { No. of } \\
\text { Respondents }\end{array}$ & $\begin{array}{l}\text { Percentage of } \\
\text { Respondents }\end{array}$ \\
\hline 1 & $\begin{array}{l}\text { Much more difficult under the new } \\
\text { system }\end{array}$ & 1 & $4 \%$ \\
\hline 2 & More difficult under the new system & 1 & $4 \%$ \\
\hline 3 & $\begin{array}{l}\text { A little more difficult under the new } \\
\text { system }\end{array}$ & 1 & $4 \%$ \\
\hline 4 & The same under the new system & 3 & $12 \%$ \\
\hline 5 & A little easier under the new system & 3 & $12 \%$ \\
\hline 6 & Easier under the new system & 9 & $36 \%$ \\
\hline 7 & Much easier under the new system & 7 & $28 \%$ \\
\hline & N/A & 34 & \\
\hline
\end{tabular}

Response Count:59

Average score: $5.44(n=25)$ 
j. Place summaries of ex parte communications in the record more quickly.

\begin{tabular}{|l|l|l|l|}
\hline $\begin{array}{l}\text { Answer } \\
\text { Number }\end{array}$ & $\begin{array}{l}\text { Corresponding } \\
\text { Written Answer }\end{array}$ & $\begin{array}{l}\text { No. of } \\
\text { Respondents }\end{array}$ & $\begin{array}{l}\text { Percentage of } \\
\text { Respondents }\end{array}$ \\
\hline 1 & $\begin{array}{l}\text { Much more difficult under the new } \\
\text { system }\end{array}$ & 0 & $0 \%$ \\
\hline 2 & More difficult under the new system & 1 & $2.6 \%$ \\
\hline 3 & $\begin{array}{l}\text { A little more difficult under the new } \\
\text { system }\end{array}$ & 1 & $2.6 \%$ \\
\hline 4 & The same under the new system & 16 & $42.1 \%$ \\
\hline 5 & A little easier under the new system & 5 & $13.1 \%$ \\
\hline 6 & Easier under the new system & 5 & $13.1 \%$ \\
\hline 7 & Much easier under the new system & 10 & $26.3 \%$ \\
\hline & N/A & 20 & \\
\hline
\end{tabular}

Response Count: 58

Average score: $5.16(\mathrm{n}=38)$

$k$. Coordinate the rulemaking intermally by allowing many people to look at the same rulemaking docket without getting in each others' way?

\begin{tabular}{|l|l|l|l|}
\hline $\begin{array}{l}\text { Answer } \\
\text { Number }\end{array}$ & Written Answer & $\begin{array}{l}\text { No. of } \\
\text { Respondents }\end{array}$ & $\begin{array}{l}\text { Percentage of } \\
\text { Respondents }\end{array}$ \\
\hline 1 & $\begin{array}{l}\text { Much more difficult under the new } \\
\text { system }\end{array}$ & 1 & $2 \%$ \\
\hline 2 & More difficult under the new system & 1 & $2 \%$ \\
\hline 3 & $\begin{array}{l}\text { A little more difficult under the new } \\
\text { system }\end{array}$ & 0 & $0 \%$ \\
\hline 4 & The same under the new system & 9 & $21 \%$ \\
\hline 5 & A little easier under the new system & 4 & $9 \%$ \\
\hline 6 & Easier under the new system & 10 & $23 \%$ \\
\hline 7 & Much easier under the new system & 18 & $42 \%$ \\
\hline & N/A & 16 & \\
\hline
\end{tabular}

Response Count: 59

Average score: $5.70(n=43)$

l. Coordinate the rulemaking externally with $O M B$ or other interested government entities?

\begin{tabular}{|l|l|l|l|}
\hline $\begin{array}{l}\text { Answer } \\
\text { Number }\end{array}$ & $\begin{array}{l}\text { Corresponding } \\
\text { Written Answer }\end{array}$ & $\begin{array}{l}\text { No. of } \\
\text { Respondents }\end{array}$ & $\begin{array}{l}\text { Percentage of } \\
\text { Respondents }\end{array}$ \\
\hline 1 & Much more difficult under the new & 1 & $2.5 \%$ \\
\hline
\end{tabular}




\begin{tabular}{|l|l|l|l|}
\hline & system & & \\
\hline 2 & More difficult under the new system & 0 & $0 \%$ \\
\hline 3 & $\begin{array}{l}\text { A little more difficult under the new } \\
\text { system }\end{array}$ & 0 & $0 \%$ \\
\hline 4 & The same under the new system & 13 & $32.5 \%$ \\
\hline 5 & A little easier under the new system & 6 & $15 \%$ \\
\hline 6 & Easier under the new system & 14 & $35 \%$ \\
\hline 7 & Much easier under the new system & 6 & $15 \%$ \\
\hline & N/A & 22 & \\
\hline
\end{tabular}

Response Count: 62

Average score: $5.23(n=40)$

m. Conduct interactive proceedings in rulemaking, such as "negotiated rulemaking"?

\begin{tabular}{|l|l|l|l|}
\hline $\begin{array}{l}\text { Answer } \\
\text { Number }\end{array}$ & $\begin{array}{l}\text { Corresponding } \\
\text { Written Answer }\end{array}$ & $\begin{array}{l}\text { No. of } \\
\text { Respondents }\end{array}$ & $\begin{array}{l}\text { Percentage of } \\
\text { Respondents }\end{array}$ \\
\hline 1 & $\begin{array}{l}\text { Much more difficult under the new } \\
\text { system }\end{array}$ & 2 & $12.5 \%$ \\
\hline 2 & More difficult under the new system & 0 & $0 \%$ \\
\hline 3 & $\begin{array}{l}\text { A little more difficult under the new } \\
\text { system }\end{array}$ & 1 & $6 \%$ \\
\hline 4 & The same under the new system & 7 & $44 \%$ \\
\hline 5 & A little easier under the new system & 2 & $12.5 \%$ \\
\hline 6 & Easier under the new system & 2 & $12.5 \%$ \\
\hline 7 & Much easier under the new system & 2 & $12.5 \%$ \\
\hline & N/A & 43 & \\
\hline
\end{tabular}

Response Count: 59

Average score: $4.19(n=16)$

n. Craft a preamble to the final rule that responds to comments and includes all relevant studies and analyses?

\begin{tabular}{|l|l|l|l|}
\hline $\begin{array}{l}\text { Answer } \\
\text { Number }\end{array}$ & $\begin{array}{l}\text { Corresponding } \\
\text { Written Answer }\end{array}$ & $\begin{array}{l}\text { No. of } \\
\text { Respondents }\end{array}$ & $\begin{array}{l}\text { Percentage of } \\
\text { Respondents }\end{array}$ \\
\hline 1 & $\begin{array}{l}\text { Much more difficult under the new } \\
\text { system }\end{array}$ & 0 & $0 \%$ \\
\hline 2 & More difficult under the new system & 1 & $2.2 \%$ \\
\hline 3 & $\begin{array}{l}\text { A little more difficult under the new } \\
\text { system }\end{array}$ & 1 & $2.2 \%$ \\
\hline 4 & The same under the new system & 17 & $38.65 \%$ \\
\hline 5 & A little easier under the new system & 7 & $15.9 \%$ \\
\hline
\end{tabular}




\begin{tabular}{|l|l|l|l|}
\hline 6 & Easier under the new system & 12 & $27.3 \%$ \\
\hline 7 & Much easier under the new system & 6 & $13.6 \%$ \\
\hline & N/A & 16 & \\
\hline
\end{tabular}

Response Count: 60

Average score: $5.05(n=44)$

o. Develop and implement appropriate archival practices relating to rulemakings (such as retiring records, etc.)?

\begin{tabular}{|l|l|l|l|}
\hline $\begin{array}{l}\text { Answer } \\
\text { Number }\end{array}$ & $\begin{array}{l}\text { Corresponding } \\
\text { Written Answer }\end{array}$ & $\begin{array}{l}\text { No. of } \\
\text { Respondents }\end{array}$ & $\begin{array}{l}\text { Percentage of } \\
\text { Respondents }\end{array}$ \\
\hline 1 & $\begin{array}{l}\text { Much more difficult under the new } \\
\text { system }\end{array}$ & 1 & $3 \%$ \\
\hline 2 & More difficult under the new system & 0 & $0 \%$ \\
\hline 3 & $\begin{array}{l}\text { A little more difficult under the new } \\
\text { system }\end{array}$ & 1 & $3 \%$ \\
\hline 4 & The same under the new system & 11 & $31 \%$ \\
\hline 5 & A little easier under the new system & 5 & $14 \%$ \\
\hline 6 & Easier under the new system & 10 & $28 \%$ \\
\hline 7 & Much easier under the new system & 8 & $22 \%$ \\
\hline & N/A & 22 & \\
\hline
\end{tabular}

Response Count: 58

Average score: $5.25(\mathrm{n}=36)$

p. Periodically evaluate and review the rule (and related rules), once promulgated?

\begin{tabular}{|l|l|l|l|}
\hline $\begin{array}{l}\text { Answer } \\
\text { Number }\end{array}$ & $\begin{array}{l}\text { Corresponding } \\
\text { Written Answer }\end{array}$ & $\begin{array}{l}\text { No. of } \\
\text { Respondents }\end{array}$ & $\begin{array}{l}\text { Percentage of } \\
\text { Respondents }\end{array}$ \\
\hline 1 & $\begin{array}{l}\text { Much more difficult under the new } \\
\text { system }\end{array}$ & 0 & $0 \%$ \\
\hline 2 & More difficult under the new system & 1 & $2.7 \%$ \\
\hline 3 & $\begin{array}{l}\text { A little more difficult under the new } \\
\text { system }\end{array}$ & 0 & $0 \%$ \\
\hline 4 & The same under the new system & 15 & $40.5 \%$ \\
\hline 5 & A little easier under the new system & 4 & $10.8 \%$ \\
\hline 6 & Easier under the new system & 9 & $24.3 \%$ \\
\hline 7 & Much easier under the new system & 8 & $21.6 \%$ \\
\hline & N/A & 25 & \\
\hline
\end{tabular}

Response Count: 62

Average score: $5.19(\mathbf{n}=37)$ 
Question 2. "When compared to the old system of paper comments, has the advent of e-rulemaking caused your agency to worry more or less about the following:"

a. Outside intervention ("hacking") into your rulemaking proceedings?

\begin{tabular}{|l|l|l|l|}
\hline $\begin{array}{l}\text { Answer } \\
\text { Number }\end{array}$ & $\begin{array}{l}\text { Corresponding } \\
\text { Written Answer }\end{array}$ & $\begin{array}{l}\text { No. of } \\
\text { Respondents }\end{array}$ & $\begin{array}{l}\text { Percentage of } \\
\text { Respondents }\end{array}$ \\
\hline 1 & $\begin{array}{l}\text { Worry much more under the new } \\
\text { system }\end{array}$ & 3 & $8.1 \%$ \\
\hline 2 & Worry more under the new system & 9 & $24.3 \%$ \\
\hline 3 & $\begin{array}{l}\text { Worry a little more under the new } \\
\text { system }\end{array}$ & 12 & $32.4 \%$ \\
\hline 4 & The same under the new system & 7 & $18.9 \%$ \\
\hline 5 & $\begin{array}{l}\text { Worry a little less under the new } \\
\text { system }\end{array}$ & 1 & $2.7 \%$ \\
\hline 6 & Worry less under the new system & 2 & $5.4 \%$ \\
\hline 7 & $\begin{array}{l}\text { Worry much less under the new } \\
\text { system }\end{array}$ & 3 & $8.1 \%$ \\
\hline & N/A & 25 & \\
\hline
\end{tabular}

Response Count: 62

Average score: $3.32(n=37)$

b. Acquiring viruses via attachments submitted in comments?

\begin{tabular}{|l|l|l|l|}
\hline $\begin{array}{l}\text { Answer } \\
\text { Number }\end{array}$ & $\begin{array}{l}\text { Corresponding } \\
\text { Written Answer }\end{array}$ & $\begin{array}{l}\text { No. of } \\
\text { Respondents }\end{array}$ & $\begin{array}{l}\text { Percentage of } \\
\text { Respondents }\end{array}$ \\
\hline 1 & $\begin{array}{l}\text { Worry much more under the new } \\
\text { system }\end{array}$ & 5 & $14 \%$ \\
\hline 2 & Worry more under the new system & 8 & $22 \%$ \\
\hline 3 & $\begin{array}{l}\text { Worry a little more under the new } \\
\text { system }\end{array}$ & 11 & $31 \%$ \\
\hline 4 & The same under the new system & 7 & $19 \%$ \\
\hline 5 & $\begin{array}{l}\text { Worry a little less under the new } \\
\text { system }\end{array}$ & 1 & $3 \%$ \\
\hline 6 & Worry less under the new system & 4 & $11 \%$ \\
\hline 7 & $\begin{array}{l}\text { Worry much less under the new } \\
\text { system }\end{array}$ & 0 & $0 \%$ \\
\hline & N/A & 26 & \\
\hline
\end{tabular}

Response Count: 62

Average score: $3.31(n=36)$ 
c. Inappropriate exposure of materials in the rulemaking docket that might contain confidential business information?

\begin{tabular}{|l|l|l|l|}
\hline $\begin{array}{l}\text { Answer } \\
\text { Number }\end{array}$ & $\begin{array}{l}\text { Corresponding } \\
\text { Written Answer }\end{array}$ & $\begin{array}{l}\text { No. of } \\
\text { Respondents }\end{array}$ & $\begin{array}{l}\text { Percentage of } \\
\text { Respondents }\end{array}$ \\
\hline 1 & $\begin{array}{l}\text { Worry much more under the new } \\
\text { system }\end{array}$ & 5 & $11 \%$ \\
\hline 2 & Worry more under the new system & 11 & $24 \%$ \\
\hline 3 & $\begin{array}{l}\text { Worry a little more under the new } \\
\text { system }\end{array}$ & 14 & $31 \%$ \\
\hline 4 & The same under the new system & 10 & $22 \%$ \\
\hline 5 & $\begin{array}{l}\text { Worry a little less under the new } \\
\text { system }\end{array}$ & 1 & $2 \%$ \\
\hline 6 & Worry less under the new system & 2 & $4 \%$ \\
\hline 7 & $\begin{array}{l}\text { Worry much less under the new } \\
\text { system }\end{array}$ & 2 & $4 \%$ \\
\hline & N/A & 17 & \\
\hline
\end{tabular}

Response Count: 62

Average score: $3.11(n=45)$

d. Inappropriate exposure of materials in the rulemaking docket that might contain copyrighted materials?

\begin{tabular}{|l|l|l|l|}
\hline $\begin{array}{l}\text { Answer } \\
\text { Number }\end{array}$ & $\begin{array}{l}\text { Corresponding } \\
\text { Written Answer }\end{array}$ & $\begin{array}{l}\text { No. of } \\
\text { Respondents }\end{array}$ & $\begin{array}{l}\text { Percentage of } \\
\text { Respondents }\end{array}$ \\
\hline 1 & $\begin{array}{l}\text { Worry much more under the new } \\
\text { system }\end{array}$ & 4 & $9 \%$ \\
\hline 2 & Worry more under the new system & 9 & $20 \%$ \\
\hline 3 & $\begin{array}{l}\text { Worry a little more under the new } \\
\text { system }\end{array}$ & 19 & $41 \%$ \\
\hline 4 & The same under the new system & 9 & $20 \%$ \\
\hline 5 & $\begin{array}{l}\text { Worry a little less under the new } \\
\text { system }\end{array}$ & 1 & $2 \%$ \\
\hline 6 & Worry less under the new system & 1 & $2 \%$ \\
\hline 7 & $\begin{array}{l}\text { Worry much less under the new } \\
\text { system }\end{array}$ & 3 & $7 \%$ \\
\hline & N/A & 16 & \\
\hline
\end{tabular}

Response Count: 62

Average score: $3.20(n=46)$ 
e. Inappropriate exposure of materials in the rulemaking docket that might contain indecent or obscene language or materials?

\begin{tabular}{|l|l|l|l|}
\hline $\begin{array}{l}\text { Answer } \\
\text { Number }\end{array}$ & $\begin{array}{l}\text { Corresponding } \\
\text { Written Answer }\end{array}$ & $\begin{array}{l}\text { No. of } \\
\text { Respondents }\end{array}$ & $\begin{array}{l}\text { Percentage of } \\
\text { Respondents }\end{array}$ \\
\hline 1 & $\begin{array}{l}\text { Worry much more under the new } \\
\text { system }\end{array}$ & 3 & $7 \%$ \\
\hline 2 & Worry more under the new system & 8 & $18 \%$ \\
\hline 3 & $\begin{array}{l}\text { Worry a little more under the new } \\
\text { system }\end{array}$ & 16 & $36 \%$ \\
\hline 4 & The same under the new system & 13 & $30 \%$ \\
\hline 5 & $\begin{array}{l}\text { Worry a little less under the new } \\
\text { system }\end{array}$ & 0 & $0 \%$ \\
\hline 6 & Worry less under the new system & 2 & $5 \%$ \\
\hline 7 & $\begin{array}{l}\text { Worry much less under the new } \\
\text { system }\end{array}$ & 2 & $5 \%$ \\
\hline & N/A & 18 & \\
\hline
\end{tabular}

Response Count: 62

Average score: $3.30(n=44)$

f. Inappropriate exposure of information in the rulemaking docket that might lead to national security problems?

\begin{tabular}{|l|l|l|l|}
\hline $\begin{array}{l}\text { Answer } \\
\text { Number }\end{array}$ & $\begin{array}{l}\text { Corresponding } \\
\text { Written Answer }\end{array}$ & $\begin{array}{l}\text { No. of } \\
\text { Respondents }\end{array}$ & $\begin{array}{l}\text { Percentage of } \\
\text { Respondents }\end{array}$ \\
\hline 1 & $\begin{array}{l}\text { Worry much more under the new } \\
\text { system }\end{array}$ & 2 & $7 \%$ \\
\hline 2 & Worry more under the new system & 0 & $0 \%$ \\
\hline 3 & $\begin{array}{l}\text { Worry a little more under the new } \\
\text { system }\end{array}$ & 7 & $25 \%$ \\
\hline 4 & The same under the new system & 15 & $54 \%$ \\
\hline 5 & $\begin{array}{l}\text { Worry a little less under the new } \\
\text { system }\end{array}$ & 1 & $4 \%$ \\
\hline 6 & Worry less under the new system & 2 & $7 \%$ \\
\hline 7 & $\begin{array}{l}\text { Worry much less under the new } \\
\text { system }\end{array}$ & 1 & $4 \%$ \\
\hline & N/A & 34 & \\
\hline
\end{tabular}

Response Count: 62

Average score: $3.82(n=28)$ 
g. Risk of information-destruction or other irretrievable loss of rulemaking information?

\begin{tabular}{|l|l|l|l|}
\hline $\begin{array}{l}\text { Answer } \\
\text { Number }\end{array}$ & $\begin{array}{l}\text { Corresponding } \\
\text { Written Answer }\end{array}$ & $\begin{array}{l}\text { No. of } \\
\text { Respondents }\end{array}$ & $\begin{array}{l}\text { Percentage of } \\
\text { Respondents }\end{array}$ \\
\hline 1 & $\begin{array}{l}\text { Worry much more under the new } \\
\text { system }\end{array}$ & 2 & $\mathbf{5} \%$ \\
\hline 2 & Worry more under the new system & 4 & $9 \%$ \\
\hline 3 & $\begin{array}{l}\text { Worry a little more under the new } \\
\text { system }\end{array}$ & $\mathbf{8}$ & $19 \%$ \\
\hline 4 & The same under the new system & 17 & $40 \%$ \\
\hline 5 & $\begin{array}{l}\text { Worry a little less under the new } \\
\text { system }\end{array}$ & 5 & $12 \%$ \\
\hline 6 & Worry less under the new system & 0 & $0 \%$ \\
\hline 7 & $\begin{array}{l}\text { Worry much less under the new } \\
\text { system }\end{array}$ & 7 & $16 \%$ \\
\hline & N/A & 19 & \\
\hline
\end{tabular}

Response Count: 62

Average Score: $4.09(n=43)$

h. Integrating (scanned) paper comments with e-mailed or electronically submitted comments?

\begin{tabular}{|l|l|l|l|}
\hline $\begin{array}{l}\text { Answer } \\
\text { Number }\end{array}$ & $\begin{array}{l}\text { Gorresponding } \\
\text { Written Answer }\end{array}$ & $\begin{array}{l}\text { No. of } \\
\text { Respondents }\end{array}$ & $\begin{array}{l}\text { Percentage of } \\
\text { Respondents }\end{array}$ \\
\hline $\mathbf{l}$ & $\begin{array}{l}\text { Worry much more under the new } \\
\text { system }\end{array}$ & 4 & $8.2 \%$ \\
\hline 2 & Worry more under the new system & 5 & $10.2 \%$ \\
\hline 3 & $\begin{array}{l}\text { Worry a little more under the new } \\
\text { system }\end{array}$ & 10 & $20.4 \%$ \\
\hline 4 & The same under the new system & 13 & $26.5 \%$ \\
\hline 5 & $\begin{array}{l}\text { Worry a little less under the new } \\
\text { system }\end{array}$ & 4 & $8.2 \%$ \\
\hline 6 & Worry less under the new system & 4 & $8.2 \%$ \\
\hline 7 & $\begin{array}{l}\text { Worry much less under the new } \\
\text { system }\end{array}$ & 9 & $18.4 \%$ \\
\hline & N/A & 13 & \\
\hline
\end{tabular}

Response Count: 62

Average score: $4.14(n=49)$ 
i. The authenticity of comments?

\begin{tabular}{|l|l|l|l|}
\hline $\begin{array}{l}\text { Answer } \\
\text { Number }\end{array}$ & $\begin{array}{l}\text { Corresponding } \\
\text { Written Answer }\end{array}$ & $\begin{array}{l}\text { No. of } \\
\text { Respondents }\end{array}$ & $\begin{array}{l}\text { Percentage of } \\
\text { Respondents }\end{array}$ \\
\hline 1 & $\begin{array}{l}\text { Worry much more under the new } \\
\text { system }\end{array}$ & 3 & $6 \%$ \\
\hline 2 & Worry more under the new system & 6 & $13 \%$ \\
\hline 3 & $\begin{array}{l}\text { Worry a little more under the new } \\
\text { system }\end{array}$ & 5 & $11 \%$ \\
\hline 4 & The same under the new system & 25 & $53 \%$ \\
\hline 5 & $\begin{array}{l}\text { Worry a little less under the new } \\
\text { system }\end{array}$ & 2 & $4 \%$ \\
\hline 6 & Worry less under the new system & 3 & $6 \%$ \\
\hline 7 & $\begin{array}{l}\text { Worry much less under the new } \\
\text { system }\end{array}$ & 3 & $6 \%$ \\
\hline & N/A & 15 & \\
\hline
\end{tabular}

Response Count: 62

Average score: $3.81(n=47)$

i. Ensuring the protection of the privacy of commenters?

\begin{tabular}{|l|l|l|l|}
\hline $\begin{array}{l}\text { Answer } \\
\text { Number }\end{array}$ & $\begin{array}{l}\text { Corresponding } \\
\text { Written Answer }\end{array}$ & $\begin{array}{l}\text { No. of } \\
\text { Respondents }\end{array}$ & $\begin{array}{l}\text { Percentage of } \\
\text { Respondents }\end{array}$ \\
\hline 1 & $\begin{array}{l}\text { Worry much more under the new } \\
\text { system }\end{array}$ & 7 & $15 \%$ \\
\hline 2 & Worry more under the new system & 6 & $13 \%$ \\
\hline 3 & $\begin{array}{l}\text { Worry a little more difficult under } \\
\text { the new system }\end{array}$ & 15 & $33 \%$ \\
\hline 4 & The same under the new system & 14 & $30 \%$ \\
\hline 5 & $\begin{array}{l}\text { Worry a little less under the new } \\
\text { system }\end{array}$ & 1 & $2 \%$ \\
\hline 6 & Worry less under the new system & 2 & $4 \%$ \\
\hline 7 & $\begin{array}{l}\text { Worry much less under the new } \\
\text { system }\end{array}$ & 1 & $2 \%$ \\
\hline & N/A & 16 & \\
\hline
\end{tabular}

Response Count: 62

Average score: $3.13(n=46)$ 